\title{
REVISTAMATĒRIA
}

ISSN 1517-7076 articles e12982, 2021

\section{Natural dyes from amazon forest: potential application in dye-sensitized solar cells}

\section{Corantes naturais da floresta Amazônica: potenciais aplicações em células solares fotosensibilizadas por corante}

\author{
Moisés do Amaral Amâncio ${ }^{1}$, Ellen Raphael ${ }^{1,2}$, \\ Yonny Romaguera-Barcelay ', Maria Oneide Silva-Moraes ${ }^{1}$, \\ Camila Macena Ruzo ", Raimundo Ribeiro Passos ${ }^{1}$, \\ Walter Ricardo Brito ${ }^{1}$
}

\footnotetext{
${ }^{1}$ Universidade Federal do Amazonas, Programa de Pós-graduação em Química. Av. Rodrigo Otávio, 6.200, Setor Norte do Campus Universitário, Coroado I, CEP: 69077-000, Manaus, AM, Brasil.

${ }^{2}$ Universidade do Estado do Amazonas, Escola Superior de Tecnologia. Av. Darcy Vargas, 1200, Parque Dez de Novembro, CEP: 69050-020, Manaus, AM, Brasil.

e-mail: wrbrito@ufam.edu.br
}

\begin{abstract}
In this work, plant dyes extracted from Amazon Forest are applied as a sensitizer in Dye-Sensitized Solar Cells. The selected plants were Euterpe oleracea, Arrabidaea chica, Bixa orellana, Genipa Americana, and Myrcia sylvatica, and the dyes were collected from fruits, leaves, seeds, pulp and seeds and stalk scrapings respectively. Characterization studies by the UV-vis spectroscopy made it possible to know the absorption spectra of each plant dye, and the X-ray diffraction technique allows the structural characterization of the nanostructured semiconductor layer. The solar cells were characterized according to their efficiency parameters (Voc, Jsc, $F F$ and $\eta(\%)$ ), obtained from the current vs voltage curves. Such parameters proved to be modest, presenting $V o c$ and Jsc values over 0.334 volts and $0.452 \mathrm{~mA} / \mathrm{cm}^{2}$ for a photosensitized cell with the dyes extracted from Genipa americana. In this way, it was possible to verify the photoelectrochemical potential of the dyes extracted from plants of the Amazon Forest.
\end{abstract}

Keywords: Plants dyes; DSSC; Grätzel Cell; solar cell; Amazon Forest.

\section{RESUMO}

Neste trabalho são aplicados corantes extraídos de plantas da Floresta Amazônica como sensibilizadores em células solares sensibilizadas por corantes. As plantas selecionadas foram Euterpe oleracea, Arrabidaea chica, Bixa orellana, Genipa americana e Myrcia sylvatica e os corantes foram coletados de frutos, folhas, sementes, polpa e sementes e do caule, respectivamente. Os estudos de caracterização através da espectroscopia UV-vis possibilitaram conhecer os espectros de absorção para cada corante e a técnica de difração de raios X permitiu a caracterização estrutural da camada semicondutora nanoestruturada. As células solares foram caracterizadas quanto a seus parâmetros de eficiência (Voc, $J s c$, FF e $\eta(\%)$ ), obtidas das curvas de corrente $v s$ potencial. Tais parâmetros se mostraram modestos, apresentando valores de Voc sobre os 0,334 volts e Jsc de $0,452 \mathrm{~mA} / \mathrm{cm}^{2}$ para célula fotossensibilizada com o corante extraído da Genipa americana. Dessa forma foi possível verificar o potencial fotoeletroquímico dos corantes extraídos de plantas da Floresta Amazônica.

Palavras-chave: corante vegetal; DSSC; célula de Grätzel; célula solar; Floresta Amazônica. 


\section{INTRODUCTION}

The yearning for new and less polluting, environment-friendly energy sources has driven research growth in pursuit of alternative energy in recent decades. Despite the growing advance related to clean technologies, global energy demand is currently still supplied, in a greater percentage, by fossil fuels (non-renewable), reaching $81.1 \%$ in the global energy matrix $[1,2]$.

Due to its high potential, solar energy presents itself as one of the most promising alternatives. The earth receives about ten thousand times more energy from the sun than our daily global consumption [3]. Even though the estimate is encouraging, the photovoltaic market is represented mainly by mono and polycrystalline silicon solar cell technologies that have an estimated production cost of US\$0,23/W. Many developing countries do not have this renewable source of energy due to its commercialization. Thus, the discoveries of new materials and technologies with low environmental impact, national sources is a way to lower cost prices [4-6].

The Dye-Sensitized Solar Cells (DSSCs) were reported for the first time in 1991 when Michael Grätzel reported a new low-cost photovoltaic device configuration. In 2019 the National Renewable Energy Laboratory (NREL) reported an efficiency certification of $12.3 \%$ for the DSSC fabricated by the École Polytechnique Fédérale de Lausanne (EPFL) [7, 8]. The typical configuration of the Grätzel devices involved the photoanode formed by the deposition of a nanostructured inorganic semiconductor $\left(\mathrm{TiO}_{2}\right)$ layer on transparent conductive glass (Indium Tin Oxide (ITO)/glass) sensitized with N719 in contact with a counter electrode formed by ITO/glass through the non-aqueous liquid electrolyte. Due to the high cost and environmental impacts of the ruthenium complex, other dyes have been considered as sensitized compounds easily obtainable, with low-costs and low environmental impact like plant dyes [9, 10].

The Amazon forest is the world's largest intact forest; it is considered the birthplace of a wide variety of natural dyes that can successfully be applied to DSSC's. Natural dyes can be easily obtained by a simple extraction method from leaves, flowers, bark, seeds, and other parts. They are distinguished by how it is incorporated into the material surface, their solubility, particle or molecular size, and chemical composition [11]. In DSSC's, dyes will guarantee the photo injection of charges in the conduction band of the semiconductor [7]. The interaction process occurs through alcoholic condensation and the chelating effect, guaranteed by hydroxyl groups $(-\mathrm{OH})$ and carboxyl groups $(-\mathrm{COOH})$ present in non-anthocyanin flavonoids, anthocyanins, carotenoids, and chlorophylls [2, 12].

In this work, we applied plant dyes from Amazon Forest as a sensitizer in DSSC's. The selected plants were Euterpe oleracea, Arrabidaea chica, Bixa orellana, Genipa Americana, and Myrcia sylvatica and the dyes were collected from fruits, leaves, seeds, pulp and seeds, and stalk scrapings respectively. The UV-vis spectroscopy made it possible to know the respective absorption spectra of each dye and the X-ray diffraction (XRD) technique characterized the semiconductor layer. The electrical characterization allowed obtaining the efficiency parameters of the respective solar cells for each dye.

\section{MATERIALS AND METHODS}

\subsection{Materials}

The following reagents were used in this work: acetone, isopropanol, methanol, and ethylene glycol, acquired from Synth ${ }^{\circledR}$, and acetonitrile and potassium iodide acquired from Biotec ${ }^{\circledR}$. Granulated metallic iodine, 20 $\mu \mathrm{m}$ graphite, and $\mathrm{TiO}_{2}$ paste from Sigma Aldrich ${ }^{\circledR}$ were also used. The conductive substrate used was ITO (Glass Coated Indian Tin Oxide) with a surface resistivity of $15 \Omega /$ sq, obtained from Lumtech. The solutions were prepared using the Millipore water, Milli- $\mathrm{Q}^{\circledR}$ purification system.

\subsection{Dyes extraction procedure}

Table 1 summarizes the respective parts of each plant used to obtain the dyes. For extracting the dye, $1 \mathrm{~mL}$ of methanol was used for each gram (g) of the raw plant material, mixed by magnetic stirring for 15 minutes, followed by resting for 2 hours before being filtered $[13,14]$. The obtaining dyes were placed in the amber flask to protect them from light. 
Table 1: Plants and the used parts.

\begin{tabular}{c|c}
\hline PLANTS & USED PARTS \\
\hline Euterpe oleracea & macerated fruits \\
\hline Arrabidaea chica & macerated dry leaves \\
\hline Bixa orellana & macerated seeds \\
\hline Genipa americana & pulp and seeds \\
\hline Myrcia sylvatica & stalk scrapings \\
\hline
\end{tabular}

Figure 1 shows pictures of each plant part used in this work and the respective dye.
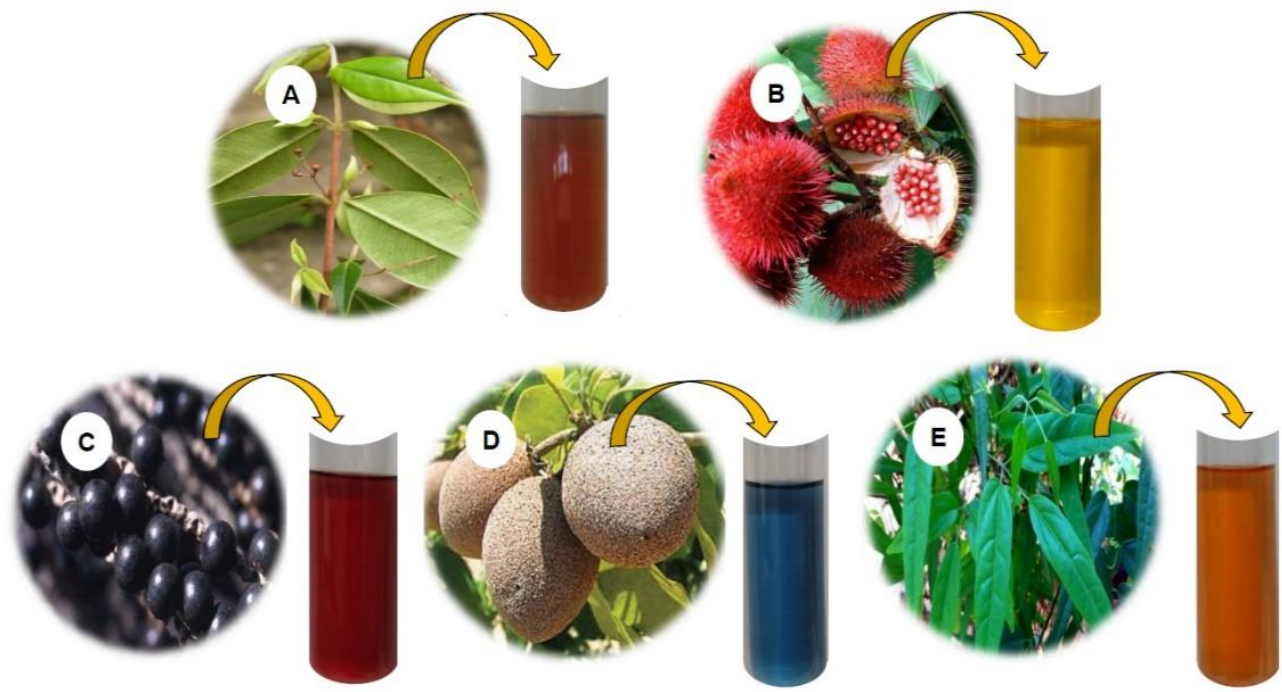

Figure 1: Dyes and plant parts used in the study. A) Myrcia sylvatica, B) Bixa orellana, C) Euterpe oleracea, D) Genipa Americana, E) Arrabidaea chica

\subsection{Characterization}

Optical characteristics of each dye were obtained through the absorption spectra collected with a Thermo Scientific UV-vis spectrophotometer model GENESYSTM $10 \mathrm{~S}$ between the 400 to $700 \mathrm{~nm}$ electromagnetic spectrum region. The crystallographic characterization of the semiconductor layer of $\mathrm{TiO}_{2}$ was performed using a Rigaku D-max Diffractometer. The measurements were performed at room temperature using $\mathrm{CuK} \alpha$ radiation in the range of $15^{\circ} \leq 2 \theta \leq 80^{\circ}$ with $0.02^{\circ}(2 \theta)$ step and counting time of $5 \mathrm{~s}$.

\subsection{Photoanode and counter electrode preparation}

In DSSC's the photoanode has the important function of absorbing and converting the light into the electric energy. As the ITO/glass is the support for the deposition of the semiconductor layer and the electrical conductivity it is necessary to ensure the perfect cleaning of the conductive ITO surface. The cleaning process was conducted by following the methodology reported by SILVA et. al [16]. Firstly, moistened cotton ${ }^{\circledR}$ swabs in acetone were used to remove the dirt and the grease present on the ITO surface. Next, the substrates were placed in a 9:1 water and industrial detergent, and subjected to mild heating for 10 minutes, after that, the substrates were subjected to successive distilled water washes to remove the detergent. Subsequently, the substrates were placed in an ultrasonic bath for 10 minutes in acetone and then 10 minutes in isopropanol, which remained in the latter until used.

The $\mathrm{TiO}_{2}$ semiconductor layer was deposited on the ITO substrate with an exposed area of $0.25 \mathrm{~cm}^{2}$ using the 
"doctor blade" method. The exposed area was defined by Scotch ${ }^{\circledR}$ tape Magic ${ }^{\mathrm{TM}}$ 810, a 0.060 mm thickness previously placed on the substrate. The tape was then removed, and $\mathrm{TiO}_{2} / \mathrm{ITO} /$ glass was submitted to $300{ }^{\circ} \mathrm{C}$ for 20 minutes to obtain the nanostructured porous $\mathrm{TiO}_{2}$. Subsequently, the substrates were immersed in the sensitizing dye for 12 hours, Figure 2.
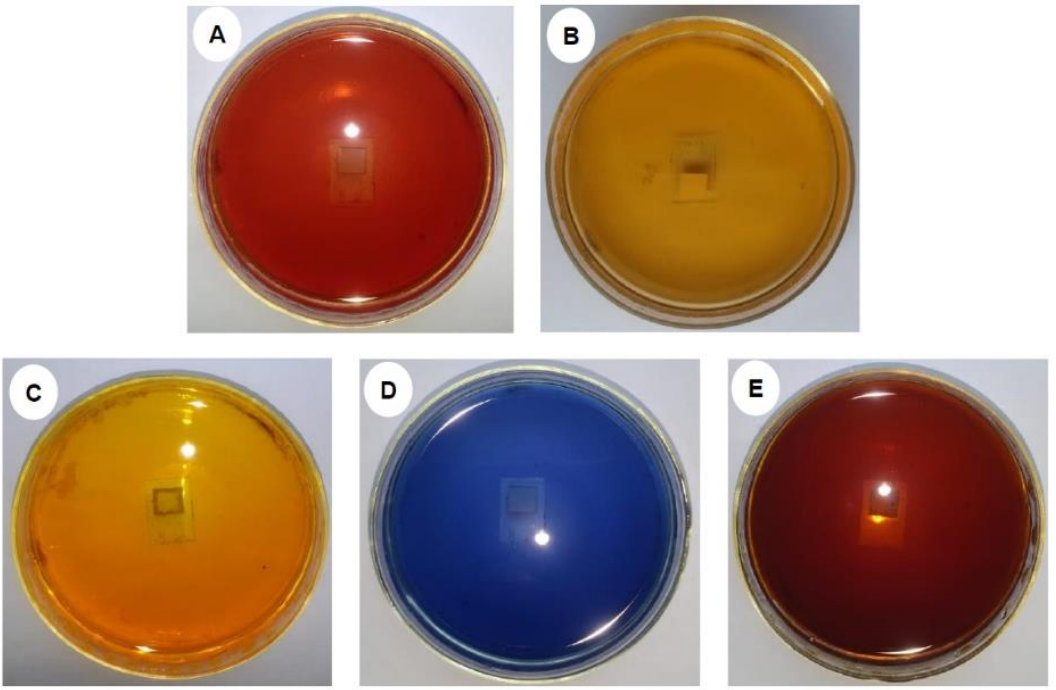

Figure 2: Photoanodes immersed in the respective sensitizing dye solutions: (A) Euterpe oleracea, (B) Arrabidaea chica, (C) Bixa orellana, (D) Genipa Americana, (E) Myrcia sylvatica.

The counter electrode is an important component of DSSC's, it collects charges from external circuits, and it enables the redox process in the electrolyte. In this study, the counter electrode is formed by the ITO/glass substrate with the same dimensions of photoanode and the active area of $0,33 \mathrm{~cm}^{2}$ that was covered with graphite [16]. Thereby, the counter electrode modification, either by graphite, platinum (Pt), graphene, conductive polymers, among others, aims to increase the charges mobility and the reduction of electrolyte in the counter electrode interface $[16,17]$.

\subsection{Cell assembly}

Figure 3 shows the DSSC's diagram of the assembly device in this work. The assembly process consists of approximating the photoanode and the counter electrode, without a short-circuit. To obtain this, it was previously placed a parafilm tape with an opening of $0.5 \times 0.5 \mathrm{~cm}$ on photoanode, exposed the sensitized $\mathrm{TiO}_{2}$. Before the final approach, the non-aqueous liquid electrolyte was placed dripping on the exposed photoanode. Non-aqueous electrolyte, formed by a redox pair $\left(\mathrm{I}^{-3} / \mathrm{I}\right)$, was prepared by dissolving $830 \mathrm{mg}$ of potassium iodide $(\mathrm{KI})$ and $60 \mathrm{mg}$ iodine $\left(\mathrm{I}_{2}\right)$ in ethylene glycol and acetonitrile (6:4) mixture [18]. 


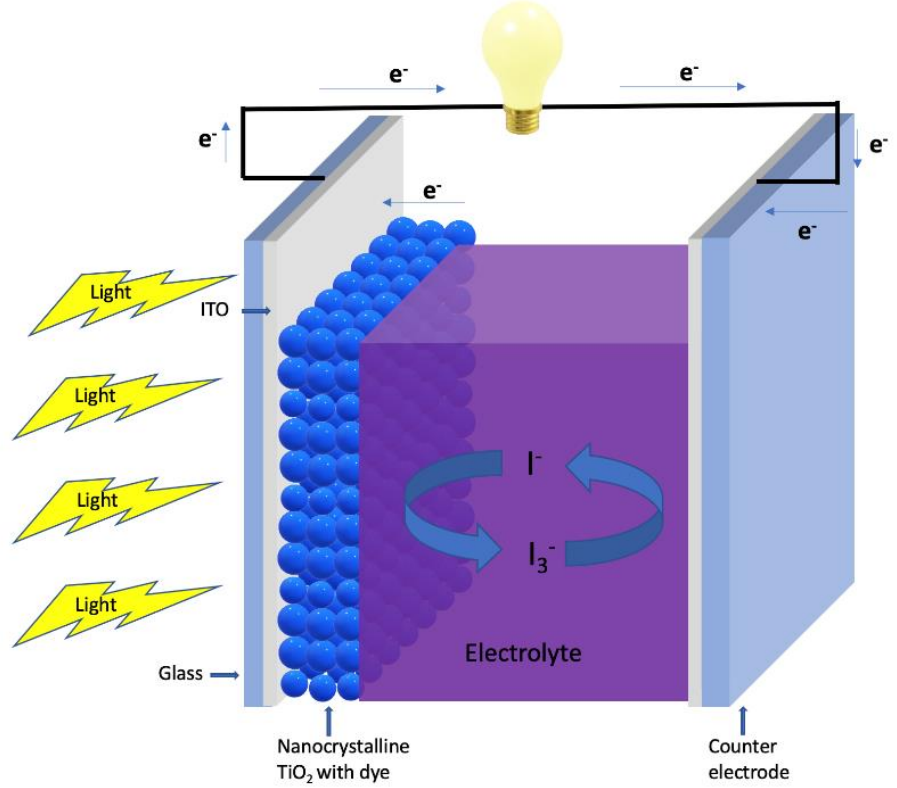

Figure 3: Schematic representation of the assembled DSSC device.

\subsection{Electrical characterization of the DSSC's}

Solar cells are characterized by the current versus voltage curves (I versus V) that allow them to obtain the necessary efficiency parameters for their evaluation. From the curves are extracted the open circuit potential $(V o c)$ (measured in zero current) and the short-circuit current density (Jsc = Icc/A) (measured in zero potential), where Icc is the short-circuit current, measured externally, and A is the effective area of the cell. The fill factor $(F F)$ of the curve and the energy conversion efficiency $(\eta)$ are calculated mathematically from the experimental data (I-V curve), equations 1 and 2, respectively.

The fill factor relates to the maximum power with the theoretical power of the cell. This parameter can be obtained from the ratio between these powers (equation 1) and is directly related to the efficiency of the cell. The value of $F F$ varies from 0 to 1 , and the closer to 1 the less resistive the system is [19].

$$
F F=\frac{J_{m} V_{m}}{J_{S C} V_{O C}}
$$

Energy conversion efficiency $(\eta)$ was obtained through the ratio between the maximum power $\left(\mathrm{P}_{\max }\right)$ and the incident light density $\left(\mathrm{P}_{\mathrm{in}}\right)$, standardized light incidence at $100 \mathrm{~mW} / \mathrm{cm}^{2}(\mathrm{AM} 1.5 \mathrm{G})$ calibrated with digital luximeter (AK310), equation 2.

$$
\eta=\frac{P_{\text {max }}}{P_{\text {in }}}=\frac{J_{m} V_{m}}{P_{\text {in }}}
$$

In this work, it was used to characterize the electrical performance of the manufacture DSSCs, a solar simulators system, LSC 100 ORIEL, and galvanostat/potentiostat Autolab PGSTAT 204N.

\section{RESULTS AND DISCUSSION}

\subsection{Plant dyes characterization}

The UV-vis spectroscopy technique has allowed the precise verification of the regions of white light absorption by the pigments used, Figure 4. The pigments are responsible for ensuring the current density in the cell, 
and therefore the importance of the investigation since the absorption region influences considerably the final performance of the device [20]. It is noted in theme-related works that pigments with light absorption in the intermediate region of the visible spectrum are those with the highest energy conversion efficiency [20-24]. Naturally the absorptions in this region (from 500 to $600 \mathrm{~nm}$ ) are characteristic of anthocyanins, a group of natural phenolic compounds [25].

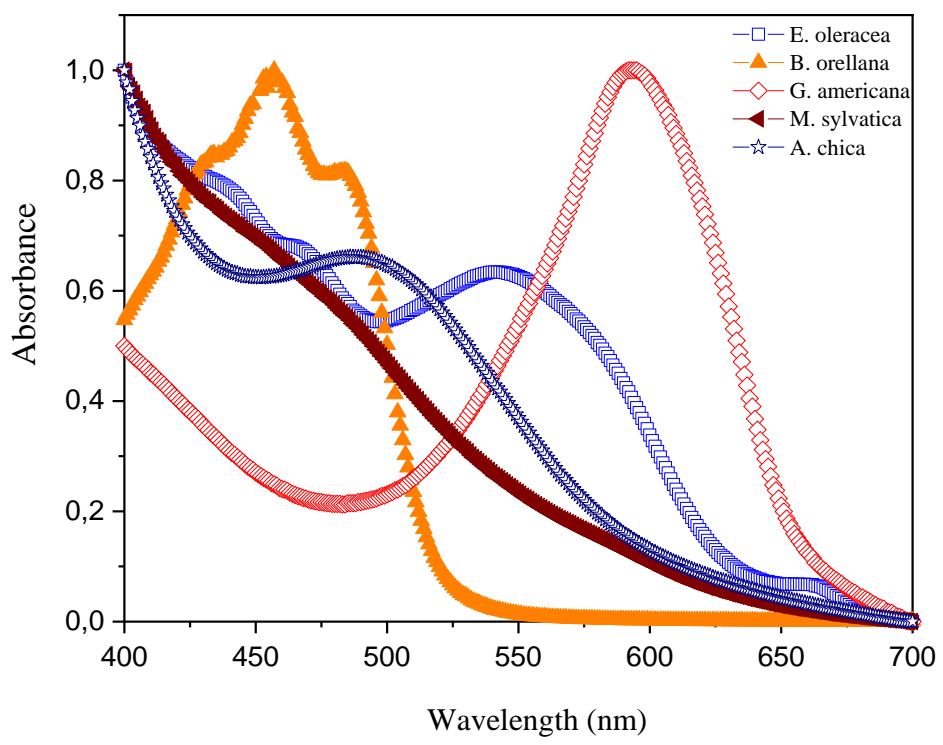

Figure 4: Standardized UV-vis absorption spectra of natural methanol pigments.

Absorptions (Figure 4), except for the Myrcia sylvática pigment, are evident, showing well-defined peaks in the visible spectrum region. For this pigment no explicit peak of maximum absorption is observed, however, two discrete peaks are noted at $457 \mathrm{~nm}$ and $591 \mathrm{~nm}$. Zhou and employees [25] attribute this discrepancy to overlapping absorption peaks. For the other pigments, the most intense peaks can be observed at $540 \mathrm{~nm}$ for Euterpe oleracea, $456 \mathrm{~nm}$ for Bixa Orellana, $598 \mathrm{~nm}$ for Genipa Americana and $500 \mathrm{~nm}$ for Arrabidaea chica. Table 3 shows the main classes of molecules present in natural dyes responsible for the light absorption in the visible region.

Table 2: Main class of molecules present in the plant dyes

\begin{tabular}{l|c|ll}
\hline PLANTS & $\begin{array}{c}\lambda \max (\mathbf{n m}) \\
\text { (higher peaks) }\end{array}$ & \multicolumn{2}{|c}{$\begin{array}{c}\text { DYES CLASSES/COMPOUND } \\
\text { REFERENCES }\end{array}$} \\
\hline Myrcia sylvatica & 457 & $\alpha$-bisabolol & PRADO, et al., (2017) [26] \\
\hline Genipa Americana & 598 & Tannins/Iridoides & ANDRADE (2016) [27] \\
\hline Arrabidaea chica & 500 & Tannins & JORGE (2008) [28] \\
\hline Euterpe oleracea & 540 & Anthocyanins & SONAI (2015) [2] \\
\hline Bixa Orellana & 456 & Carotenoids & ZHOU (2011); GARCIA (2012) [10, 29] \\
\hline
\end{tabular}

\subsection{Characterization of the nanostructure semiconductor layer}

Figure 5 a) shows the X-ray diffraction (XRD) patterns of nanostructured $\mathrm{TiO}_{2}$ deposited as a semiconductor layer on the ITO/glass substrate. Also identified are the rutile (b) and anatase (c) polymorphs characteristic of $\mathrm{TiO}_{2}$ [30-32]. 


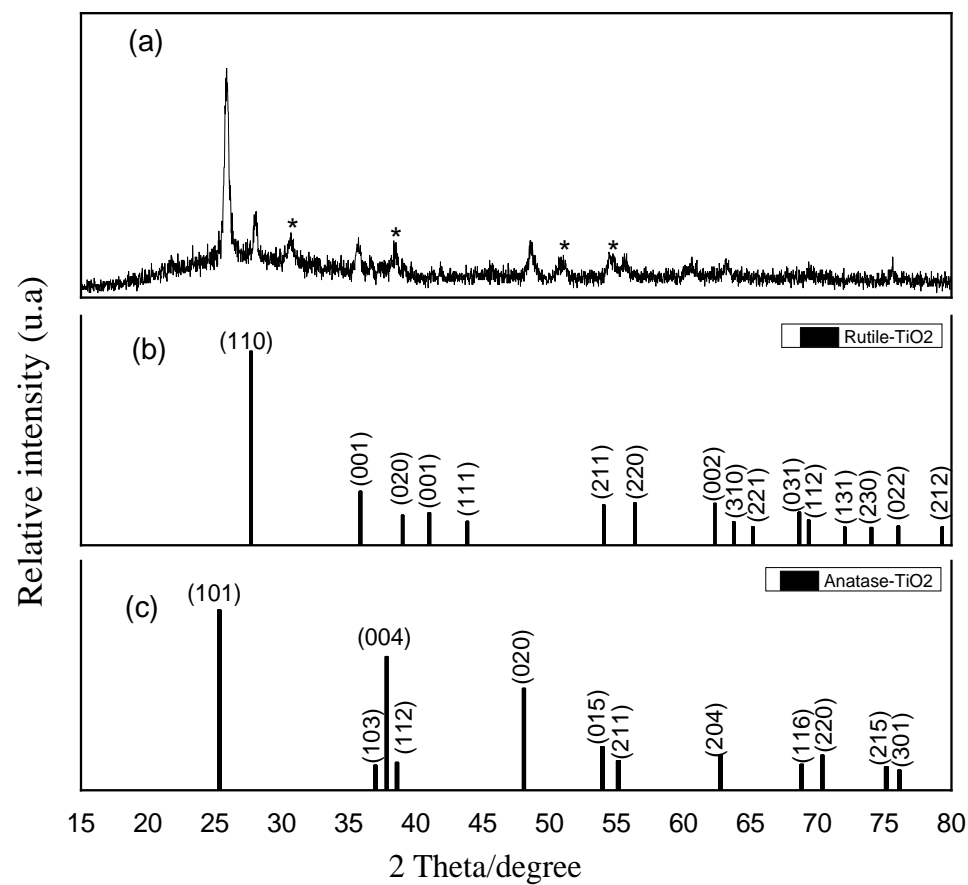

Figure 5: XRD patterns of the nanostructured $\mathrm{TiO}_{2}$ (a) and reported rutile (b) and anatase(c) [29-31]. *Diffraction patterns of substrate ITO/glass.

In DSSCs it is desired that the photoanode is formed by a nanostructured $\mathrm{TiO}_{2}$ mesoporous layer that guarantees a good diffusion of the dye and the electrolyte [33, 34]. XRD technique is used to demonstrate the structural characteristics of the deposited $\mathrm{TiO}_{2}$ layer on the ITO/glass substrate. Figure 5 a) shows the XRD pattern of $\mathrm{TiO}_{2}$, that presents five characteristic diffractions belonging to the anatase phase attributed to the crystalline planes at 25.86 (101), 38.36 (112), 48.58 (020), 69.34 (220), and 75.62 (215) with tetragonal structure, spatial group I41/amdZ and symmetry 141 [30], five other peaks were attributed to the ITO/glass substrate at 30.68 (222), 35.72 (411), 50.86 (440), 54.5 (121), and 60.48 (622), and three peaks, 28.04 (110), 55.74 (220), and 63.16 (002) to the rutile phase with tetragonal structure, space group P42/mnm, and symmetry 136 [32]. According to the $\mathrm{XRD}$ analysis, the $\mathrm{TiO}_{2}$ layer shows the rutile and anatase characteristics in accordance with the recommended composition reported for applications in DSSCs [35 - 39].

\subsection{Electrical characterization of DSSCs}

The photoelectrochemical parameters of the cells sensitized with these pigments are organized in Table 3 . The cells were evaluated according to open circuit voltage (Voc), short-circuit current density (Jsc), fill factor (FF), and energy conversion efficiency $(\eta)$.

Table 3: Electrical parameters of DSSCs sensitized with plant dyes.

\begin{tabular}{|c|c|c|c|c|c|c|}
\hline NATURAL DYES & $\begin{array}{l}\text { SENSITIZED PHO- } \\
\text { TOANODES }\end{array}$ & DSSC & Voc (V) & $\mathrm{Jsc}\left(\mathrm{mA} / \mathrm{cm}^{2}\right)$ & FF & $\eta(\%)$ \\
\hline Myrcia sylvatica & & & 0,301 & 0,141 & 0,2 & 0,01 \\
\hline Genipa americana & & & 0,334 & 0,452 & 0,5 & 0,08 \\
\hline
\end{tabular}




\begin{tabular}{lllllll}
\hline Arrabidaea chica & 0,283 & 0,279 & 0,4 & 0,02 \\
\hline Euterpe oleracea & 0,334 & 0,242 & 0,3 & 0,03 \\
\hline & & & & & \\
\hline
\end{tabular}

The energy conversion efficiencies $(\eta)$ obtained for these cells are modest, ranging from 0.01 to $0.08 \%$. The voltage (Voc) and current density (Jsc) values displayed ranged from 0.283 to 0.334 volts and 0.141 and $0.452 \mathrm{~mA} / \mathrm{cm} 2$, respectively. The most expressive performance is shown for the cell whose sensitization was performed with the pigment extracted from Genipa americana, Table 3. However, plant dyes have not shown the best energy conversion efficiencies in DSSCs [10]. Some factors like the instability by the temperature variations [2] and the device assembly [40] may contribute to the low performance of DSSCs.

Figure 6 shows two of the experimental curves obtained from the devices using the pigments of Arrabidaea chica and Euterpe oleracea. The dotted rectangles were placed to show the differences between the ideal and experimental maximum power presented by the devices. In general, the experimental cells presented low values of FF, ranging from 0.2 to 0.5 , considered quite resistive systems. The effects can be noted in the efficiency values, in which the resistivity interferes directly [19].

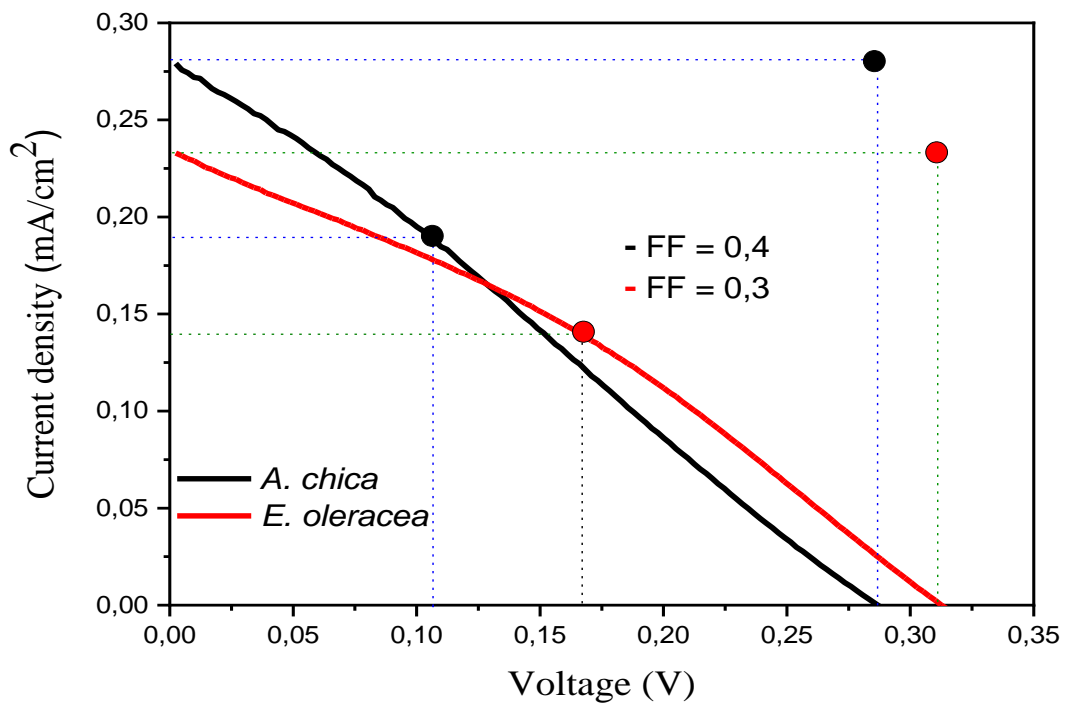

Figure 6: IV curves of DSSCs sensitized by extracted dyes of Arrabidaea chica and Euterpe oleracea. Black and red circles represent the ideal behavior of Pmax.

The DSSCs manufactured in this work displayed electrical performance as reported in the literature [2, $9,22]$. To improve the electrical performance, it is possible to optimize the fabrication parameters and selected materials that ensure the lowest internal resistance, facilitate the electrons flow, and increase the efficiency of electron injection. Furthermore, it is possible to increase the dye photostability and to reduce the electron 
recombination with the oxidized dye, and with the species of the electrolytic solution, as well as the electron recombination due to weak interaction of the dye and the conduction band of nanostructured $\mathrm{TiO}_{2}[5,11,19$, 41-43].

\section{CONCLUSION}

The work presents the manufacture and characterization of DSSCs sensitized with plant dyes from Amazon Forest. Characterization studies by the UV-vis spectroscopy made it possible to know the absorption spectra of each plant dye and the XRD technique allows the structural characterization of the nanostructured semiconductor layer. On the other hand, electrical characterization allowed us to obtain the efficiency parameters of the respective solar cells for each dye. Experimental results showed the potential of the plant dyes extracted from Amazon Forest to respond to the demand for renewable energy sources specifically for low-cost solar cells.

\section{ACKNOWLEDGMENTS}

We would like to thank CAPES (Coordenação de Aperfeiçoamento de Pessoal de Nível Superior), CNPq (Conselho Nacional de Desenvolvimento Científico e Tecnológico) and FAPEAM (Fundação de Amparo à Pesquisa do Estado do Amazonas) for financial support.

\section{BIBLIOGRAPHY}

[1] LI, D., HEIMERIKS, G., ALKEMADE, F. "The emergence of renewable energy technologies at country level: relatedness, international knowledge spillovers and domestic energy markets", doi: 10.1080/13662716.2020.1713734. Ind Innov, pp. 1-23, jan. 2020.

[2] SONAI, G.G., JÚNIOR, M.A.M., NUNES, J.H.B. et al., "Células solares sensibilizadas por corantes naturais: Um experimento introdutório sobre energia renovável para alunos de graduação”, doi: 10.5935/0100-4042.20150148. Quim Nova, v. 38, n. 10, pp. 1357-1365, 2015.

[3] CRESESB, "Centro de Referência para a Energia Solar e Eólica Sérgio de Salvo Brito", 2020.

[4] GODIBO, D.J., ANSHEBO, S.T., ANSHEBO, E.T.Y. "Dye Sensitized Solar Cells Using Natural Pigments from Five Plants and", 117, v. 26, n. 1, pp. 92-101, 2015.

[5] RAPHAEL, E., JARA, D.H., SCHIAVON, E.M.A. "Optimizing photovoltaic performance in CuInS2 and CdS quantum dot-sensitized solar cells by using an agar-based gel polymer electrolyte", doi: 10.1039/c6ra27635k. RSC Adv, v. 7, n. 11, pp. 6492-6500, 2017.

[6] VDMA, International Technology Roadmap for Photovoltaic, Itrpv. 11th Editi (2020) 76. https://itrpv.vdma.org/en/ueber-uns.

[7] O'REGAN, B., GRÄTZEL, M. “A low-cost, high-efficiency solar cell based on dye-sensitized colloidal TiO2 films”, doi: 10.1038/353737a0. Nature, v. 353, n. 6346, pp. 737-740, 1991.

[8] NREL, "National Renewable Energy Laboratory”, 2020.

[9] HUG, H., BADER, M., MAIR, P. et al."Biophotovoltaics: Natural pigments in dye-sensitized solar cells", doi: 10.1016/j.apenergy.2013.10.055. Appl Energy, v. 115, pp. 216-225, 2014.

[10] ZHOU, H., WU, L., GAO, Y., et al. "Dye-sensitized solar cells using 20 natural dyes as sensitizers", doi: 10.1016/j.jphotochem.2011.02.008. J Photochem Photobiol A Chem, v. 219, n. 2-3, pp. 188-194, 2011.

[11] LUDIN, N.A., AL-ALWANI MAHMOUD, A.M., BAKAR MOHAMAD, A., et al., "Review on the development of natural dye photosensitizer for dye-sensitized solar cells", doi: 10.1016/j.rser.2013.12.001. Renew Sustain Energy Rev, v. 31, pp. 386-396, 2014.

[12] POLO A.S., MURAKAMI IHA, N.Y. "Blue sensitizers for solar cells: Natural dyes from Calafate and Jaboticaba”, doi: 10.1016/j.solmat.2006.02.006. Sol Energy Mater Sol Cells, v. 90, n. 13, pp. 1936-1944, 2006.

[13] HOSSEINNEZHAD, M., ROUHANI, S., GHARANJIG, K. "Extraction and application of natural pigments for fabrication of green dye-sensitized solar cells", doi: 10.1016/j.opelre.2018.04.004. Optoelectronics Rev, v. 26, n. 2, pp. 165-171, 2018.

[14] AL-ALWANI, M.A.M., MOHAMAD, A.B., KADHUM, A.A.H., et al., "Effect of solvents on the extraction of natural pigments and adsorption onto TiO2 for dye-sensitized solar cell applications", doi: 10.1016/j.saa.2014.11.018. Spectrochim Acta - Part A Mol Biomol Spectrosc, v. 138, pp. 130-137, 2015.

[15] SILVA-MORAES, M.O., et al., "Geometry-dependent DNA-TiO2 immobilization mechanism: A spec- 
troscopic approach", doi: 10.1016/j.saa.2018.03.081. Spectrochim Acta - Part A Mol Biomol Spectrosc, v. 199, pp. 349-355, 2018.

[16] WU, J. et al., "Counter electrodes in dye-sensitized solar cells", doi: 10.1039/c6cs00752j. Chem Soc Rev, v. 46, n. 19, pp. 5975-6023, 2017.

[17] THOMAS, S., DEEPAK, T.G., ANJUSREE, G.S., et al., "A review on counter electrode materials in dye-sensitized solar cells", doi: 10.1039/c3ta13374e. J Mater Chem A, v. 2, n. 13, pp. 4474-4490, 2014.

[18] CHAKRABARTI, T., DEY, A., SARKAR, S.K. "Comparative analysis of physical organic and inorganic Dyesensitized solar cell”, doi: 10.1016/J.OPTMAT.2018.05.009. Opt Mater (Amst), v. 82, pp. 141-146, Mar. 2018.

[19] VITORETI, A.B.F., CORRÊA, L.B., RAPHAEL, E., et al., "Células solares sensibilizadas por pontos quânticos", doi: 10.21577/0100-4042.20160192. Quim Nova, v. 40, n. 4, pp. 436-446, 2016.

[20] WONGCHAREE, K., MEEYOO, V., CHAVADEJ, S. "Dye-sensitized solar cell using natural dyes extracted from rosella and blue pea flowers", doi: 10.1016/j.solmat.2006.11.005. Sol Energy Mater Sol Cells, v. 91, n. 7, pp. 566-571, 2007.

[21] ROY, M.S., BALRAJU, P., KUMAR, M., et al., "Dye-sensitized solar cell based on Rose Bengal dye and nanocrystalline TiO2", doi: 10.1016/j.solmat.2008.02.022. Sol Energy Mater Sol Cells, v. 92, n. 8, pp. 909-913, 2008.

[22] ZHANG, D., LANIER, S.M., DOWNING, J.A., et al. "Betalain pigments for dye-sensitized solar cells", doi: 10.1016/j.jphotochem.2007.07.038. J Photochem Photobiol A Chem, v. 195, n. 1, pp. 72-80, 2008.

[23] TEOLI, F. et al., "Role of $\mathrm{pH}$ and pigment concentration for natural dye-sensitized solar cells treated with anthocyanin extracts of common fruits", doi: 10.1016/j.jphotochem.2015.10.009. J Photochem Photobiol A Chem, v. 316, pp. 24-30, 2016.

[24] GARCIA, C.G., POLO, A.S., MURAKAMI IHA, N.Y. "Photoelectrochemical solar cell using extract of Eugenia jambolana Lam as a natural sensitizer", doi: 10.1590/S0001-37652003000200004. An Acad Bras Cienc, v. 75, n. 2, pp. 163-165, 2003.

[25] ZHOU, H., WU, L., GAO, Y., et al.,"Journal of Photochemistry and Photobiology A : Chemistry Dyesensitized solar cells using 20 natural dyes as sensitizers", doi: 10.1016/j.jphotochem.2011.02.008. "Journal Photochem Photobiol A Chem, v. 219, n. 2-3, pp. 188-194, 2011.

[26] PRADO, A.S. et al., "Experimental and theoretical description of the optical properties of Myrcia sylvatica essential oil", doi: 10.1007/s00894-017-3365-1. J Mol Model, v. 23, n. 7, 2017.

[27] Andrade, E.L. "Obtenção de corante azul em pó de Jenipapo: Análise experimental dos processos de oxidação induzida e leito de jorro", Universidade Federal do Pará, 2016.

[28] JORGE, M.P. et al., "Evaluation of wound healing properties of Arrabidaea chica Verlot extract", doi: 10.1016/j.jep.2008.04.024. J Ethnopharmacol, v. 118, n. 3, pp. 361-366, 2008.

[29] GARCIA, C.E.R., BOLOGNESI, V.J., DIAS, J.F.G., et al. "Carotenoides bixina e norbixina extraídos do urucum (Bixa orellana L.) como antioxidantes em produtos cárneos", doi: 10.1590/s0103-

84782012000800029. Cienc Rural, v. 42, n. 8, pp. 1510-1517, 2012.

[30] VIVAS, L., DELGADO, G.E., LERET, P., et al., "Electron Paramagnetic Resonance study of hopping in CCTO mixed with TiO2", doi: 10.1016/j.jallcom.2016.09.034. J Alloys Compd, v. 692, pp. 212-218, 2017.

[31] NOBRE, F.X. et al., "Facile synthesis of nTiO2 phase mixture: Characterization and catalytic performance", doi: 10.1016/j.materresbull.2018.09.019. Mater Res Bull, v. 109, pp. 60-71, 2019.

[32] HENDERSON, M.A. "A surface science perspective on TiO2 photocatalysis", doi: 10.1016/j.surfrep.2011.01.001. Surf Sci Rep, v. 66, pp. 185-297, 2011.

[33] BAI, F.-Q., LI, W., ZHANG, H.-X. "Theoretical Studies of Titanium Dioxide for Dye-Sensitized Solar Cell and Photocatalytic Reaction”, W. Li, Org. Rijeka: IntechOpen, 2017, p. Ch. 10.

[34] SÁNCHEZ-GARCÍA, M. A., BOKHIMI, X., MALDONADO-ÁLVAREZ, A. et al., "Effect of Anatase Synthesis on the Performance of Dye-Sensitized Solar Cells", Nanoscale Res Lett, v. 10, n. 1, pp. 991, dez. 2015.

[35] CASTRO-BELTRÁN, A., et al., "Titanium butoxide molar ratio effect in the TiO2 nanoparticles size and methylene blue degradation”, doi: 10.1016/j.ijleo.2017.11.185. Optik (Stuttg), v. 157, pp. 890-894, 2018. [36] AL-TAWEEL, S.S., SAUD, H.R. "New route for synthesis of pure anatase TiO2 nanoparticles via utrasound-assisted sol-gel method”, J Chem Pharm Res, v. 8, n. 2, pp. 620-626, 2016. 
[37] CUNHA, D.L., KUZNETSOV, A., Achete, C. A., et al. "Immobilized TiO2 on glass spheres applied to heterogeneous photocatalysis: Photoactivity, leaching and regeneration process”, doi: 10.7717/peerj.4464.PeerJ, v. 2018, n' 3, pp. 1-19, 2018.

[38] LEE, H., KIM, J., KIM, D.Y., et al., "Co-sensitization of metal free organic dyes in flexible dye sensitized solar cells”, doi: 10.1016/j.orgel.2017.10.003. Org Electron, v. 52, pp. 103-109, 2018.

[39] ABATE, A. et al., Nanomaterials for Solar Cell Applications. Chennai: Elsevier, 2019.

[40] AGNALDO, J.S., BASTOS, J.B.V., CRESSONI, J.C. et al., "Células solares de TiO2 sensibilizado por corante”, doi: 10.1590/s1806-11172006000100010. Rev Bras Ensino Fis, v. 28, n. 1, pp. 77-84, 200.

[41] COUTINHO, N. D. F., "Células Solares Sensibilizadas por Corante”, p. 106, 2014.

[42] NAN, H., SHEN, H.P., WANG, G. et al. "Studies on the optical and photoelectric properties of anthocyanin and chlorophyll as natural co-sensitizers in dye sensitized solar cell”, doi:

10.1016/j.optmat.2017.07.036. Opt Mater (Amst), v. 73, pp. 172-178, 2017.

[43] PATROCÍNIO, A.O.T., MURAKAMI IHA, N.Y. "Em busca da sustentabilidade: Células solares sensibilizadas por extratos naturais", doi: 10.1590/s0100-40422010000300016. Quim Nova, v. 33, n. 3, pp. 574578,2010

\section{ORCID}

Moisés do Amaral Amâncio

https://orcid.org/0000-0001-5676-8762

Ellen Raphael

https://orcid.org/0000-0002-5617-8428

Yonny Romaguera-Barcelay

https://orcid.org/0000-0002-8091-1212

Maria Oneide Silva-Moraes

https://orcid.org/0000-0003-2605-4413

Camila Macena Ruzo

https://orcid.org/0000-0002-9847-5877

Raimundo Ribeiro Passos

https://orcid.org/0000-0002-5478-9604

Walter Ricardo Brito

https://orcid.org/0000-0002-6493-0237 